\title{
Ehlers-Danlos syndrome in chronic pain patient. Case report
}

\author{
Síndrome de Ehlers-Danlos em paciente com dor crônica. Relato de caso
}

Paola Lima Bem-Haja' ${ }^{1}$, José Carlos Canga ${ }^{1}$, Yuri Louro de Abreu², Felipe Minotti Bedoni'

DOI 10.5935/1806-0013.20160035

\section{ABSTRACT}

BACKGROUND AND OBJECTIVES: Ehlers-Danlos Syndrome is a connective tissue disease which becomes disabling in some cases. This study aimed at presenting a rare case diagnosed in the Ambulatory of Symptoms Control and Palliative Care with severe pain.

CASE REPORT: Male patient, 17 years old, who came to the ambulatory complaining of widespread pain for 4 years. He referred history of joint hypermobility noticed since childhood.

CONCLUSION: Based on clinical history and physical evaluation, in addition to Brighton criteria, patient was diagnosed as having hypermobility-type Ehlers-Danlos Syndrome.

Keywords: Hypermobility, Joint pain, Multidisciplinary management.

\section{RESUMO}

JUSTIFICATIVA E OBJETIVOS: A síndrome de EhlersDanlos é uma doença do tecido conjuntivo que em alguns casos torna-se incapacitante. O objetivo deste estudo foi apresentar um caso raro diagnosticado no Ambulatório de Controle de Sintomas e Cuidados Paliativos com quadro doloroso importante.

RELATO DO CASO: Paciente do gênero masculino, 17 anos, apresentou-se ao ambulatório com queixa de dor no corpo generalizada havia 4 anos. Referia história de hipermobilidade articular notada desde a infância.

CONCLUSÃO: Neste caso realizou-se o diagnóstico de Síndrome de Ehlers-Danlos, tipo hipermobilidade, com base na história clínica e no exame físico, além dos critérios de Brighton. A adesão ao tratamento multidisciplinar mostrou impactante melhora na qualidade de vida do paciente.

Descritores: Dor articular, Hipermobilidade, Tratamento multidisciplinar.

1. Faculdade de Medicina do ABC, Departamento de Anestesiologia. Santo André, SP, Brasil 2. Hospital Estadual Mário Covas, Santo André, SP, Brasil.

Submitted in October 30, 2015

Accepted for publication in April 12, 2016.

Conflict of interests: none - Sponsoring sources: none.

Correspondence to:

Paola Lima Bem-Haja

Rua Doutor Henrique Calderazzo, 321

Ambulatório de Controle de Sintomas do Hospital Estadual Mário Covas

09190-615 Santo André, SP, Brasil.

E-mail:paolabemhaja@globo.com

( ) Sociedade Brasileira para o Estudo da Dor

\section{INTRODUCTION}

Ehlers-Danlos syndrome (EDS) is a connective tissue disorder characterized by joint hypermobility and sagging, skin hyperextensibility, atrophic scars, brittle skin and bruises ${ }^{1-3}$. It is a genetic disease where diagnosis is primarily clinical, with different manifestations encompassing more than 10 clinical syndromes. Most common types are types I, II and III, characterized by joint and skin hypermobility, brittle skin and atrophic scars (types I and II) and joint hypermobility, pain and luxations (type III) ${ }^{4}$. EDS has also been associated to psychiatric disorders, fatigue, dizziness and musculoskeletal pain. Collagen is the protein supporting connective tissue (skin, ligaments, tendons, internal organ walls, cartilage, blood vessels) and defects in its synthesis may result in muscle weakness leading to above-described signs and symptoms ${ }^{3}$. Classic EDS is responsible for $50 \%$ to $90 \%$ of all cases ${ }^{5,6}$ and its prevalence is estimated in 1:20000 in the population ${ }^{7}$. Joint hypermobility is a sign of classic EDS published in the literature. This sign may be evaluated with the Brighton scale where a score of 5 or more, out of 9 , defines hypermobility ${ }^{8}$.

This study aimed at reporting a case of patient with widespread joint pain, especially on knee, initially diagnosed as having "growing pains" by a basic attention service (Specialties Ambulatory) and then with the diagnostic hypothesis of EDS, based on symptoms, including chronic musculoskeletal pain, widespread muscle weakness and history of hypermobility.

\section{CASE REPORT}

Male patient, 17 years old, $50 \mathrm{~kg}, 1.70 \mathrm{~m}$, student, natural from Sáo Paulo-SP and living in Diadema-SP. Patient presented to the Symptoms Control ambulatory complaining of widespread body pain for four years, especially on both knees. Patient referred pain worsening along the day, associated to severe lower limbs weakness.

Patient has joint hypermobility history since childhood. Previous orthopedic evaluation has diagnosed ligament laxity. Patient reported follow-up with endocrinopediatrics due to low stature with approximately seven years of age, being treated with somatotropin. During childhood he was diagnosed with depressive disorder, however without intervention. Recent laboratory and radiographic exams of feet and hands, in addition to electroneuromyography were normal. Patient is adequately developing and currently attends the third grade of high school. At physical evaluation, he presented good general status, without heart and lungs auscultation changes. 
Face and skin evaluation has shown eyelid sagging and palate arching.

Musculoskeletal system had joint crackles, excessive elbows and fingers curvature, and has scored 6 after Brighton criteria maneuvers (Table 1). Presence of scoliosis and flat feet, as well as hypermobility. Knee ultrasound has shown bilateral joint recess changes with increased joint fluid.

Pain score varied from 5 to 8 , according to numeric verbal pain scale (NVS) from zero to 10 . Therapy was started with simple analgesics, in addition to recommendations to practice water physical activities and physiotherapy for muscle and joint strengthening. Patient was encouraged to start psychological treatment for better understanding the disease and pain self-control. Along treatment, analgesic dose was adjusted: $500 \mathrm{mg}$ dipirone every $6 \mathrm{~h}$ to control crises.

Patient was oriented to return every month. As from the first month of therapy there has been pain improvement. To evaluate patient's quality of life, the World Health Organization Quality of Life Group (WHOQOL) research tool adapted and validated to Brazil was used, which contains 26 items encompassing vitality, emotional aspects and mental health, social aspects, pain and general health status. Its score varies from 1 to 5 . According to the tool, last two weeks were taken as reference and positive impact on quality of life of patient after beginning of treatment was observed, according to domains of tools used for analysis. Patient had mean NVS scores between 3 and 5, without paroxysmal crises.

Currently, patient is followed-up in the outpatient clinic and drug doses are adjusted and verified as needed. During next medical visits, patient was confident on medical assistance. Based on clinical history and physical evaluation, in addition to Brighton criteria, patient was diagnosed with EDS. Interconsultation in the Genetic Ambulatory, School of Medicine of $\mathrm{ABC}$ was requested to maintain multidisciplinary followup, as well as investigation for classification and guidance with regard to prognosis and therapy.

Table 1. Brighton diagnostic criteria

\begin{tabular}{lcc}
\hline Able to: & Right & Left \\
\hline $\begin{array}{l}\text { Passive dorsiflexion of fifth metacarpal bone } \\
>90^{\circ}\end{array}$ & 1 & 1 \\
$\begin{array}{l}\text { Oppose the thumb to the volar aspect of ip- } \\
\text { silateral forearm }\end{array}$ & 1 & 1 \\
Hyperextend to elbow $>10^{\circ}$ & 1 & 1 \\
Hyperextend the knee $>10^{\circ}$ & 1 & 1 \\
$\begin{array}{l}\text { Put the hands flat on the floor without ben- } \\
\text { ding the knees }\end{array}$ & 1 & \\
Total & & 9 \\
\hline
\end{tabular}

\section{DISCUSSION}

Pain is a common symptom associated to different EDS forms ${ }^{10}$. In 1994, Lumley et al. ${ }^{11}$ were the first to point to a possible role of chronic pain on quality of life of EDS patients, when they studied the psychosocial status of 48 individuals with different EDS.
Voermans et al. ${ }^{12}$ have published results of a study with 273 patients with different types of EDS especially the classic, hypermobility and vascular types; and as a common result they have found severe pain associated to functional impairment. Pain intensity was related to hypermobility, luxations and previous surgeries ${ }^{12}$. Clinically, recurrent joint pain is the most common presentation of hypermobility EDS, reflected by the application of Brighton diagnostic criteria ${ }^{13}$. Hypermobility EDS may be diagnosed by the presence of two major criteria or one major and two minor criteria, or in the presence of four minor criteria.

Some symptoms of EDS and its subtypes include muscle cramps $^{14}$, fibromyalgia ${ }^{15,16}$ and neuropathic pain ${ }^{17,18}$. Our case shows clinical signs of hypermobility typical of EDS. Diagnosis was made as from 2 major criteria: arthralgia in at least four joints for at least three months and hypermobility, in addition to already described ultrasound results. After specific maneuvers, patient was able to oppose the thumb bilaterally to the forearm ( 2 points), to bilaterally perform dorsiflexion of the fifth finger ( 2 points) and to hyperextend the elbow $>15^{\circ}$ ( 2 points).

Symptoms such as chronic fatigue, dizziness and depression have confirmed the diagnosis. Natural EDS history says that pain is a variable symptom and that its consequences are influenced by adaptation strategies developed by each patient to cope with pain ${ }^{10}$. Berglund et al. ${ }^{19}$ have published the results of a study with 365 patients above 18 years of age with EDS from the National Sweden Association and have pointed to high anxiety and depression levels. Our report confirms the excellent therapeutic response to dipirone and to the multidisciplinary therapy shown by our patient and a short follow-up time. It is also worth stressing that most patients do not have such an effective response to medication used alone (without association, for example, of opioids or surgical procedures).

Diagnostic process of hypermobility EDS may be seen as a challenge, due to current diagnostic criteria and complex patients' profile. Lack of standardization for some major clinical symptoms (pain and connective tissue laxity) and the lack of inclusion of other clinical signs are the most frequently reported problems in the clinical practice. In addition to issues regarding diagnosis, the lack of consensus on treatment or general guidance for treatment adaptation are also a problem. Even for experienced physicians, it is still difficult to accurately identify patients and to determine which factors should be changed for a successful treatment. The recognition of this specific phenotype of musculoskeletal pain would be the first and critical step for the development of new and more effective therapy programs ${ }^{20}$.

\section{CONCLUSION}

Ehler-Danlos syndrome is a complex and multisystemic condition, the major challenge of which is accurate diagnosis. For such, interdisciplinary cooperation should be encouraged and issues regarding clinical heterogeneity, disease classification, adequate pain diagnosis and treatment should be addressed. 


\section{ACKNOWLEDGMENTS}

Authors acknowledge Prof. Deoclécio Tonelli (in memoriam) for his extreme dedication to patients of the "Ambulatório de Controle de Sintomas e Cuidados Paliativos", Hospital Estadual Mário Covas.

\section{REFERENCES}

1. Giunta C, Nuytinck L, Raghunath M, Hausser I, De Paepe A, Steinmann B. Homozygous Gly530Ser substitution in COL5A1 causes mild classical Ehlers-Danlos syndrome. Am J Med Genet. 2002;109(4):284-90.

2. Malfait F, Coucke P, Symoens S, Loeys B, Nuytinck L, De Paepe A. The molecular basis of classic Ehlers-Danlos syndrome: a comprehensive study of biochemical and molecular findings in 48 unrelated patient. Hum Mutat. 2005;25(1):28-37.

3. Malfait F, Wenstrup RJ, De Paepe A. Clinical and genetic aspects of Ehlers-Danlos syndrome, classic type. Genet Med. 2010;12(10):597-605.

4. Mao JR, Bristow J. The Ehlers-Danlos syndrome: on beyond collagens. J Clin Invest. 2001;107(9):1063-9.

5. Steinmann B, Royce PM, Superti-Furga A. The Ehlers-Danlos Syndrome. In: Steinmann PMRaB, editor. Connective Tissue and Its Heritable Disorders: Molecular, Genetic, and Medical Aspects. $2^{\text {nd }}$ ed. Hoboken, NJ, USA: John Wiley \& Sons Inc; 2003.

6. Castori M. Ehlers-danlos syndrome, hypermobility type: an underdiagnosed hereditary connective tissue disorder with mucocutaneous, articular, and systemic manifestations. ISRN Dermatol. 2012;2012:751768.

7. Byers P. Disorders of collagen biosynthesis and structure. In: Scriver CR, Beaudet AR, Sly WS, Valle D, editors. The metabolic and molecular bases of inherited disease. $2^{\text {nd }}$ ed. Edinburgh: Churchill Livingstone; 2001.1065-81p.

8. Beighton P, De Paepe A, Steinmann B, Tsipouras P, Wenstrup RJ. Ehlers-Danlos syndromes: revised nosology, Villefranche, 1997. Ehlers-Danlos National Foundation
(USA) and Ehlers-Danlos Support Group (UK). Am J Med Genet. 1998;77(1):31-7. 9. Fleck MP, Louzada S, Xavier M, Chachamovich E, Vieira G, Santos L, et. al. [Aplication of the Portuguese version of the abbreviated instrument of quality life WHOQOL=bref]. Rev Saude Publica. 2000;34(2):178-83. Portuguese.

10. Castori M, Morlino S, Celletti C, Ghibellini G, Bruschini M, Grammatico P, et al Re-writing the natural history of pain and related symptoms in the joint hypermobility syndrome/Ehlers-Danlos syndrome, hypermobility type. Am J Med Genet A. 2013;161A(12):2989-3004.

11. Lumley MA, Jordan M, Rubenstein R, Tsipouras P, Evans MI. Psychosocial functioning in the Ehlers-Danlos syndrome. Am J Med Genet. 1994;53(2):149-52.

12. Voermans NC, Knoop H, Bleijenberg G, van Engelen BG. Pain in ehlers-danlos syndrome is common, severe, and associated with functional impairment. J Pain Symptom Manage. 2010;40(3):370-8.

13. Grahame R, Bird HA, Child A. The revised (Brighton 1998) criteria for the diagnosis of benign joint hypermobility syndrome (BJHS) J Rheumatol. 2000;27(7):1777-9.

14. Beighton P, Horan F. Orthopaedic aspects of the Ehlers-Danlos syndrome. J Bone Joint Surg Br. 1969;51(3):444-53.

15. Ofluoglu D, Gunduz OH, Kul-Panza E, Guven Z. Hypermobility in women with fibromyalgia syndrome. Clin Rheumatol. 2006;25(3):291-3.

16. Sendur OF, Gurer G, Bozbas GT. The frequency of hypermobility and its relationship with clinical findings of fibromyalgia patients. Clin Rheumatol. 2007;26(4):485-7.

17. Voermans NC, Drost G, van Kampen A, Gabreels-Festen AA, Lammens M, Hame BC, et al. Recurrent neuropathy associated with Ehlers-Danlos syndrome. J Neurol. 2006;253(5):670-1.

18. Voermans NC, Knoop H, van Engelen BG. High frequency of neuropathic pain in Ehlers-Danlos syndrome: an association with axonal polyneuropathy and compression neuropathy? J Pain Symptom Manage. 2011;41(5):e4-6, author reply e6-7.

19. Berglund B, Pettersson C, Pigg M, Kristiansson P. Self reported quality of life, anxiety and depression in individuals with Ehlers-Danlos syndrome (EDS): a questionnaire study. BMC Musculoskelet Disord. 2015;16:89.

20. Scheper MC, de Vries JE, Verbunt J, Engelbert RH. Chronic pain in hypermobility syndrome and Ehlers-Danlos syndrome (hypermobility type): it is a challenge. J Pain Res. 2015;20;8:591-601. 